\title{
Analisa Kepuasan Mahasiswa Terhadap E-Learning Menggunakan Teknik Machine Learning
}

\author{
Isse Liana Septiani ${ }^{1,}$, Abdul Rasyid Faiq Hadinata ${ }^{1}$, Agus Bahtiar ${ }^{2}$, Nana Suarna ${ }^{3}$, \\ Nining $\mathbf{R}^{4}$ \\ $1^{*}$ Sistem Informasi; STMIK IKMI CIREBON; JI. Perjuangan No.10B, Karyamulya, Kec. Kesambi, \\ Kota Cirebon, Jawa Barat 45131, 0231-490480; e-mail: info.ikmicirebon@gmail.com. \\ ${ }^{1}$ Sistem Informasi; STMIK IKMI CIREBON; JI. Perjuangan No.10B, Karyamulya, Kec. Kesambi, \\ Kota Cirebon, Jawa Barat 45131, 0231-490480; e-mail: info.ikmicirebon@gmail.com. \\ 2 Sistem Informasi; STMIK IKMI CIREBON; JI. Perjuangan No.10B, Karyamulya, Kec. Kesambi, \\ Kota Cirebon, Jawa Barat 45131, 0231-490480; e-mail: info.ikmicirebon@gmail.com. \\ ${ }^{3}$ Teknik Informatika; STMIK IKMI CIREBON; JI. Perjuangan No.10B, Karyamulya, Kec. \\ Kesambi, Kota Cirebon, Jawa Barat 45131, 0231-490480; e-mail: info.ikmicirebon@gmail.com. \\ ${ }^{4}$ Komputerisasi Akuntansi; STMIK IKMI CIREBON; JI. Perjuangan No.10B, Karyamulya, Kec. \\ Kesambi, Kota Cirebon, Jawa Barat 45131, 0231-490480; e-mail: info.ikmicirebon@gmail.com. \\ * Korespondensi: e-mail: info.ikmicirebon@gmail.com
}

Diterima: 15 Maret 2021; Review: 24 Maret 2021; Disetujui: 30 Maret 2021, 137-146

Cara sitasi: Septiani IL, Hadinata ARF, Bahtiar A, Suarna N, Nining R. 2021. Analisa Kepuasan Mahasiswa Terhadap E-Learning Menggunakan Teknik Machine Learning. Informatics for Educators and Professionals. Vol (5) No.2 :Hal: .137-146

\begin{abstract}
Abstrak: E-Learning merupakan salah satu media pembelajaan yang didukung oleh teknologi komputer dan jaringan internet yang didalamnya terdapat konten pembelajaran serta dapat diakses kapanpun dan dimanapun tanpa adanya keterbatasan jarak dan waktu. Kepuasan mahasiswa pada pembelajaran machine learning memiliki keterkaitan yang kuat. Semakin berkualitas penerapan pembelajaran di machine learning, maka semakin tinggi pula pencapaian kepuasan mahasiswa. Penelitian ini menggunakan metode algoritma naïve bayes classifier dengan menggunakan aplikasi rapidminer. Menggunakan teknik pengumpulan data kuantitatif dalam mengumpulkan data yang akan dijadikan sebagai sampel. Sumber data yang diperoleh dengan cara wawancara kepada pihak Biro Administrasi Akademik dan Kemahasiswaan (BAAK) STMIK IKMI Cirebon dan menyebarkan link kuesioner kepada responden yaitu mahasiswa kelas reguler sore secara online dengan menggunakan Google Form. Atribut yang digunakan pada data mining sistem pembelajaran mahasiswa kelas reguler sore antara lain: Ketersediaan Indigoes (A1), Penggunaan Indigoes (A2), Pengujian Indigoes (A3), Aktifitas Indigoes (A4), Kemudahan Indigoes (A5). Dari hasil pengolahan akan didapat hasil (Hasil Kepuasan) dan memperoleh klasifikasi tingkat kepuasan mahasiswa terhadap e-learning dimasa pandemic covid-19. Tujuan penelitian ini adalah ingin mengklasifikasikan tingkat kepuasan mahaiswa dengan penerapan data mining menggunakan algoritma naïve bayes classifier dalam mengetahui klasifikasi kepuasan mahaiswa dalam pembelajaran menggunakan e-learning dimasa pandemic covid-19. Pada penelitian ini diperoleh hasil tingkat akurasi sebesar $100 \%$, recall $100 \%$ dan precision $100 \%$ dan hasil kepuasan mahasiswa terhadap elearning dikategorikan "PUAS. Hasil penelitian ini diharapkan dapat dimanfaatkan sebagai tolok ukur dalam mengetahui tingkat kepuasan mahasiswa pada pembelajaran melalui e-learning dimasa pandemic yang sangat berpengaruh terhadap sistem pembelajaran mahasiswa.
\end{abstract}

Kata kunci: Klasifikasi, Kepuasan Mahasiswa, Metode Naïve Bayes, Machine Learning

Abstract: E-Learning is a learning medium that is supported by computer technology and internet networks which contain learning content and can be accessed anytime and anywhere without any distance and time limitations. Student satisfaction in machine learning has a strong relationship. The more quality the application of learning in machine learning, the higher the 
achievement of student satisfaction. Based on the observation result, students of regular afternoon class at STMIK IKMI Cirebon on average have worked and spend more time from morning to evening working. So that when learning using machine learning through the network during the Covid-19 pandemic, it was seen that the student response was not fast enough in understanding their learning. This study uses the naïve Bayes classifier algorithm using the rapidminer application. Using quantitative data collection techniques in collecting data that will be used as samples. Sources of data obtained by interviewing the Bureau of Academic Administration and Student Affairs (BAAK) STMIK IKMI Cirebon and distributing questionnaire links to respondents, namely students of regular evening classes online using Google Form. The attributes used in the data mining system for regular afternoon class student learning include: Availability of Indigoes (A1), Use of Indigoes (A2), Testing of Indigoes (A3), Indigo Activities (A4), Ease of Indigoes (A5) From the processing results, the results will be obtained (Satisfaction Results) and obtain a classification of the level of student satisfaction with elearning during the Covid-19 pandemic.The purpose of this study is to classify the level of student satisfaction with the application of data mining using the naïve Bayes classifier algorithm in knowing the classification of student satisfaction in learning using e-learning during the Covid-19 pandemic. In this study, an accuracy rate of $100 \%$ was obtained or included in the category of satisfaction with e-learning. The results of this study are expected to be used as a benchmark in determining the level of student satisfaction in learning through e-learning during the pandemic which greatly affects the student learning system.

Keywords: Classification, Student Satisfaction, Naïve Bayes Method, Machine Learning,.

\section{Pendahuluan}

E-Learning merupakan salah satu media pembelajaan yang didukung oleh teknologi komputer dan jaringan internet, didalamnya terdapat konten pembelajaran serta dapat diakses kapanpun dan dimanapun tanpa adanya keterbatasan jarak dan waktu [1]. E-learning atau pembelajaran elektronik pertama kali diperkenalkan oleh Universitas lionis di UrbanaChampaign dengan menggunakan sistem instruksi berbasis komputer (computer assisted instruction) dan komputer bernama PLATO[1]. Seperti pada perguruan tinggi swasta di Sekolah Tinggi Managemen Informatika Dan Komputer (STMIK) IKMI Cirebon yang menerapkan pembelajaran menggunakan e-learning.

Dalam penerapan pembelajaran menggunakan e-learning diperguruan tinggi tentu sangat penting untuk diketahui tingkat kepuasan mahasiswa terhadap e-learning. Kepuasan mahasiswa pada pembelajaran machine learning memiliki keterkaitan yang kuat. Semakin berkualitas penerapan pembelajaran di machine learning, maka semakin tinggi pula pencapaian kepuasan mahasiswa. Kepuasan mahasiswa merupakan esensial dalam TQM (Total Quality Management), oleh sebab itu sebuah Perguruan Tinggi harus mengidentifikasi kebutuhan para mahasiswa secara cermat dan berusaha memuaskan dengan memandang bahwa mahasiswa sebagai pelanggan utama yang harus dilayani[2]. Salah satu untuk mengetahui tingkat kepuasan tercapainya hasil pembelajaran terhadap e-learning pada mahasiswa kelas reguler sore dalam mengklasifikasikan kepuasan mahasiswa dimasa pandemic covid-19 diperlukan klasifikasi data mining dengan menggunakan metode algoritma naïve bayes classifier untuk dapat mengklasifikasikan tingkat kepuasan mahasiswa kelas reguler sore terhadap e-learning.

Penggunaan data mining dengan metode Naïve Bayes sudah banyak diterapkan dalam penelitian. Pada penelitian terdahulu yang dilakukan oleh Abdul Hakim dan Suherman [3]. dalam penelitiannya menerapkan data mining metode naïve bayes classification dalam sistem prediksi kehadiran masyarakat pemilih. Masalah pada penelitian tersebut yaitu masyarakat tidak menggunakan hak pilihnya atau golput, dari hasil penelitian nilai Accuracy $75,56 \%$, nilai Precision 86,84\%, dan nilai Recall 84,62\%. Hasilnya menyimpulkan bahwa algoritma Naïve Bayes memiliki kinerja yang baik dari segi akurasi, presisi dan recall untuk memprediksi kehadiran masyarakat pemilihan umum.

Arif Senja Fitriani[4], menerapkan data mining untuk memprediksi partisipasi pemilihan gubernur. Ada beberapa masalah pada penelitian tersebut yaitu banyak kepemilikan identitas penduduk yang invalid atau tidak sesuai, tidak memiliki identitas penduduk, sehingga berdampak pada saat pemilihan umum. Peneliti tersebut menggunakan metode Naïve Bayes. Hasil prediksi 97\% prediksi kebenarannya dan 3\% prediksi kesalahannya. 
Berdasarkan hasil observasi bahwa mahasiswa kelas reguler sore di STMIK IKMI Cirebon rata-rata sudah bekerja dan lebih banyak menghabiskan waktu dari pagi sampai sore untuk bekerja. Sehingga pada saat pembelajaran perkuliahan melalui machine learning dalam jaringan, terlihat respon mahasiswa yang kurang cepat dalam pemahaman belajarnya. Dikarenakan mahasiswa kelas reguler sore tidak seperti mahasiswa kelas reguler pagi yang lebih memiliki banyak waktu untuk belajar yang dapat mendukung softskill mahasiswa untuk menunjukkan bakat-bakatnya seperti Unit Kegiatan Mahasiswa (UKM) dan Program Kreativitas Mahasiswa (PKM).

Dari hasil pengamatan pada saat pembelajaran dimasa pandemic kelas reguler sore, kepuasan mahasiswa dalam mengikuti pembelajaran melalui e-learning belum diketahui tingkat kepuasannya. Karena dalam proses pembelajaran melalui dalam jaringan kemampuan pemahaman dari setiap mahasiswa berbeda-beda. Hal ini karena keaadaan mahasiswa kelas reguler sore yang sudah banyak menghabiskan waktunya untuk bekerja dan memiliki sisa waktu yang sedikit, sehingga menjadi faktor penyebab. Perlu adanya penyesuaian terhadap kemampuan mahasiswa dalam mengolah informasi yang disampaikan. Agar tujuan dan sasaran pembelajaran dapat tercapai, karena dari evaluasi kegiatan belajar pada mahasiswa kelas reguler sore merupakan upaya dalam meningkatkan sistem pembelajaran.

\section{Metode Penelitian}

Penelitian ini menggunakan metode klasifikasi data mining algoritma Naive Bayes Classifier. Dengan melakukan pengolahan data kuesioner terlebih dahulu menggunakan Microsoft Office Excel dan mengambil nilai rata-rata dari setiap atribut. Maka akan didapat hasil preprocessing data akumulasi. Kemudian data tersebut akan dilakukan pengujian menggunakan software Rapidminer untuk dapat mengklasifikasikan kepuasan mahasiswa terhadap machine learning.

\section{Data Mining}

Jenis penelitian yang dilakukan yaitu menerapkan data mining, dalam menemukan model dan fungsi untuk menggambarkan konsep data. Sifat penelitian ini yaitu objektif bertujuan untuk mengetahui apa yang sedang diteliti agar bisa memecahkan masalah, menggunakan pendekatan penelitian kuantitatif. Penelitian kuantitatif merupakan penelitian yang bersifat objektif serta menjelaskan hubungan antar variabel dan menguji teori.

\section{Algoritma Naïve Bayes}

Algoritma naive bayes merupakan algoritma klasifikasi probalistik yang diterapkan untuk menghitung frekuensi dan kombinasi nilai di kumpulan data yang diberikan [5]. Naïve bayes classifier merupakan salah satu algoritma yang digunakan dalam data mining yang menerapkan teori Bayes dalam klasifikasi[6]. Bayes terbukti memiliki akurasi dan kecepatan yang tinggi saat diaplikasikan ke dalam database dengan data yang besar[7].

Berikut bentuk umum yang berlaku pada algoritma Naive Bayes:

$$
P(H \backslash X)=(P(X \backslash H) \cdot P(H)) /(P(X))[8]
$$

Keterangan:

$\mathrm{X} \quad$ : Data dengan class yang belum diketahui

H : Hipotesis data merupakan suatu class spesifik

$\mathrm{P}(\mathrm{H} \mid \mathrm{X})$ : Probabilitas hipotesis $\mathrm{H}$ berdasar kondisi $\mathrm{X}$ (posteriori probabilitas)

$\mathrm{P}(\mathrm{H}) \quad$ : Probabilitas hipotesis $\mathrm{H}$ (prior probabilitas)

$P(X \mid H)$ :Probabilitas $X$ berdasarkan kondisi pada hipotesis $H$

$P(X) \quad$ : Probabilitas $X$

Variabel Dan Indikator

Variabel merupakan konstruk atau sifat yang akan dipelajari atau dikatakan sebagai suatu sifat yang diambil dari suatu nilai yang berbeda (different values). Pada penelitian skripsi ini terdapat 2 (dua) variabel yang harus diteliti: 
1. Variabel Independen (X): bisa disebut dengan variabel prediksi. Merupakan hasil manipulasi. Atribut atau potensial kasus yang diberikan pada investigasi dari hasil penelitian.

2. Variabel Dependen (Y): dapat dikatakan sebagai variabel output, kriteria, konsekuen, variabel terikat atau variabel yang dipengaruhi atau yang menjadi sebab akibat.

\section{Hasil dan Pembahasan \\ Hasil Penelitian}

Subjek dalam penelitian ini adalah mahasiswa STMIK IKMI Cirebon tahun angkatan 2016 kelas reguler sore Teknik Informatika semua program studi yang akan dijadikan sebagai responden. Populasi yang belum diketahui, maka peneliti menanyakan ke Biro Administrasi Akademik dan Kemahasiswaan (BAAK) dalam mengetahui data jumlah mahasiswa angkatan 2016. Dari hasil informasi BAAK jumlah mahasiswa aktif semester 8 kelas reguler pagi dan reguler sore atau malam angkatan 2016 yaitu 168 mahasiswa, maka peneliti hanya mengambil data mahasiswa kelas reguler sore sebagai populasi dari permasalahan yang didapat oleh peneliti terhadap tingkat kepuasan mahasiswa kelas reguler sore dalam pembelajaran menggunakan machine learning. Data mahasiswa kelas reguler sore teknik informatika semua program studi berjumlah 129 mahasiswa, maka data tersebut sebagai populasi. Dari populasi yang sudah diketahui peneliti akan mengambil sampel. Dalam menentukan sampel peneliti menggunakan rumus slovin sebagai berikut:

$$
\mathrm{n}=\frac{N}{1+N e^{2}}[9]
$$

Keterangan :

$\mathrm{n}=$ Jumlah sampel

$\mathrm{N}=$ Jumlah seluruh populasi

$\mathrm{e}=$ Error ketidak telitian atau taraf kesalahan

Penelitian ini e $=0,05(5 \%)$, maka perhitungan sampelnya $n=\frac{129}{1+129 \cdot(0.05)^{2}}=97.54253308$

Maka sampel yang akan digunakan dalam penelitian ini berjumlah 97 mahasiswa yang akan dijadikan sebagai responden dalam penyebaran kuesioner. Atribut yang digunakan pada data mining sistem pembelajaran mahasiswa kelas reguler sore antara lain: Ketersediaan Indigoes (A1), Penggunaan Indigoes (A2), Pengujian Indigoes (A3), Aktifitas Indigoes (A4), Kemudahan Indigoes (A5). Dari hasil pengolahan akan didapat (Hasil Kepuasan) dan memperoleh klasifikasi kepuasan mahasiswa terhadap pembelajaran menggunakan machine learning indigoes kelas reguler sore.

Pelaksanaan penelitian dilakukan di STMIK IKMI Cirebon. Dengan melakukan wawancara pertemuan antara dua orang atau lebih untuk saling bertukar informasi dan ide melalui tanya jawab, sehingga dapat disimpulkan dalam suatu topik tertentu. Adapun aspek yang perlu dinilai tingkat kepuasan mahasiswa terhadap machine learning indigoes dikelompokan seperti pada tabel 1 dibawah ini:

Tabel 1 Aspek yang dinilai

\begin{tabular}{cl}
\hline & \multicolumn{1}{c}{ Aspek yang dinilai } \\
\hline No & Ketersediaan Indigoes \\
\hline 1 & Indigoes menyediakan isi yang sangat sesuai dengan kebutuhan \\
\hline 3 & Indigoes menyediakan isi yang bermanfaat \\
\hline 4 & Indigoes menyediakan isi yang cukup lengkap \\
\hline Penggunaan Indigoes \\
\hline 5 & Indigoes mudah digunakan \\
\hline 6 & Indigoes tampilannya menarik \\
\hline 7 & Indigoes bersifat user-friendly \\
\hline 8 & Indigoes stabil dan lancar
\end{tabular}




\begin{tabular}{ll}
\hline \multicolumn{1}{c}{ Aspek yang dinilai } \\
\hline Pengujian Indigoes \\
\hline 9 & Metode pengujian seperti tugas-tugas melalui Indigoes bersifat fair/adil \\
\hline 10 & Metode pengujian tersebut memberi tahu hasil dengan cepat \\
\hline 11 & Tugas-tugas yang ada di Indigoes mudah dipahami \\
\hline 12 & Metode pengujian bersifat aman \\
\hline Aktifitas Indigoes \\
\hline 13 & Indigoes memungkinkan saya untuk mengontrol kemajuan belajar saya \\
\hline 14 & Indigoes memungkinkan saya mempelajari materi yang diberikan disetiap matakuliah \\
\hline 15 & Indigoes merekam kemajuan pembelajaran saya \\
\hline 16 & Indigoes merekam kinerja pembelajaran saya \\
\hline 17 & Indigoes Mempermudah saya mendiskusikan pertanyaan kepada para dosen \\
\hline 18 & Indigoes Mempermudah saya mendiskusikan pertanyaan kepada mahasiswa lain \\
\hline 19 & Interaktifitas pembelajaran melalui Indigoes membantu penguasaan materi \\
\hline 20 & Interaktifitas pembelajaran melalui Indigoes memberikan rasa senang/puas \\
\hline
\end{tabular}

Sumber : Hasil Penelitian (2021)

Sehingga akan didapat pengelompokan kriteria aspek yang dinilai antara lain: Ketersediaan Indigoes, Penggunaan Indigoes, Pengujian Indigoes, Aktifitas Indigoes dan Kemudahan Indigoes. Dalam memperoleh tingkat kepuasan mahasiswa terhadap machine learning, peneliti menggunakan angket atau kuesioner secara online dengan menggunakan Google Form yang disebarkan kepada 97 mahasiswa angkatan 2016 kelas reguler sore teknik informatika semua program studi. Kemudian dilakukan transformation data untuk mengubah data hasil pembagian kuesioner menjadi bentuk yang sesuai untuk di-mining dan dilakukan pengolahan terlebih dahulu menggunakan Microsoft Office Excel dengan melakukan pengolahan data kuesioner dengan cara mengambil nilai rata-rata dari setiap variabel. Data awal dikelompokan terlebih dahulu sesuai kriteria pada aspek yang dinilai. Deskripsi jawaban responden dilakukan dengan menghitung nilai rata-rata jawaban responden terhadap masingmasing pertanyaan berdasarkan atribut. Untuk mengkategorikan rata-rata jawaban responden digunakan interval kelas yang dicari dengan rumus sebagai berikut:

$$
\text { IntervalKelas }=\frac{\text { nilai tertinggi }- \text { nilai terendah }}{\text { jumlah jawaban }}=\frac{4-1}{4}=0,75
$$

Dengan nilai interval kelas 0,75 kemudian disusun kriteria rata-rata jawaban responden yang disajikan menjadi 4 kategori yaitu Sangat Baik, Baik, Cukup Baik dan Tidak Baik.

Berdasarkan dari data awal sebelum dilakukan pengolahan, kemudian data diolah menggunakan Microsoft Office Excel kuesioner dengan cara mengambil nilai rata-rata dari setiap variabel . Adapun bobot nilai dari setiap jawaban yaitu Sangat Setuju $=4$, Setuju $=3$, Cukup Setuju = 2, Tidak Setuju =1. Dan kuesioner berjumlah 20 butir pernyataan .

Untuk menentukan jarak interval antar total skor dapat digunakan rumus seperti berikut:

$$
\text { jaraklnterval }=\frac{\text { nilai tertinggi }- \text { nilai terendah }}{\text { jumlah skola }}
$$

Berdasarkan rumus di atas, maka didapatkan nilai jarak interval sebagai berikut:

$$
\text { JarakInterval }=\frac{80-20}{4}=15
$$

Setelah mendapatkan nilai jarak interval yaitu 15 maka skala rating kepuasan responden . Sampel data yang didapat sebanyak 97 responden sebagai dataset. Dari jumlah 97 record kemudian dataset dibagi menjadi dua yaitu data training $80 \%$ (78 record) sebagai data latih dan data testing 20\% (19 record) sebagai data uji. Dalam menentukan data training dan data testing 
digunakan dengan cara split data. Berikut adalah gambar proses split data: Setelah dilakukan proses split data, maka akan didapat data training berjumlah 78 record dan sisanya akan dijadikan data testing sebagai data uji. Berdasarkan data yang didapat terdapat 78 data latih yang terdiri dari lima atribut yaitu: Ketersediaan Indigoes (A1), Penggunaan Indigoes (A2), Pengujian Indigoes (A3), Aktifitas Indigoes (A4), Kemudahan Indigoes (A5) dan class label Hasil Kepuasan.

Kemudian peneliti mengklasifikasikan terlebih dahulu probabilitas class atau label pada data latih dengan Naïve Bayes Classifier. Karena dalam penelitian ini menggunakan data training sebagai acuan. Berikut cara perhitungannya menggunakan metode algoritma Naïve Bayes Classifier:

Probabilitas class atau label (Hasil Kepuasan)

$P($ Sangat Puas $)=5 / 78=0.064$

$P($ Puas $)=72 / 78=0.923$

$\mathrm{P}($ Cukup Puas $)=1 / 78=0.013$

Tabel 2 Nilai Probabilitas

Sumber : Hasil Penelitian (2021)

\begin{tabular}{cccc}
\hline \multicolumn{5}{c}{ PROBABILITAS HASIL KEPUASAN MAHASISWA } \\
\hline Kepuasan & Jumlah Data & Jumlah Seluruh Data & Hasil \\
\hline Sangat Puas & 5 & 78 & 0,064 \\
\hline Puas & 72 & 78 & 0,923 \\
\hline Cukup Puas & 1 & 78 & 0,013 \\
\hline
\end{tabular}

Pengukuran data yang dilakukan terhadap data training sebagai acuan dari penelitian ini, maka peneliti melakukan data uji dari 19 responden. Untuk mengetahui Hasil Kepuasan dari data baru, maka perlu mengklasifikasikan terlebih dahulu probabilitas class atau label pada data latih dengan Nä̈ve Bayes Classifier. Berikut cara perhitungannya menggunakan metode algoritma Nä̈ve Bayes Classifier: Karena nilai probabilitas class Sangat Puas dan class Cukup Puas lebih kecil dari nilai probabilitas class Puas, maka dapat disimpulkan bahwa data responden No.3 diatas termasuk dalam kategori "PUAS". Hasil pengujian dari data testing dapat dilihat pada Tabel Berikut Ini

Tabel 3 Prediksi Algoritma Naïve Bayes

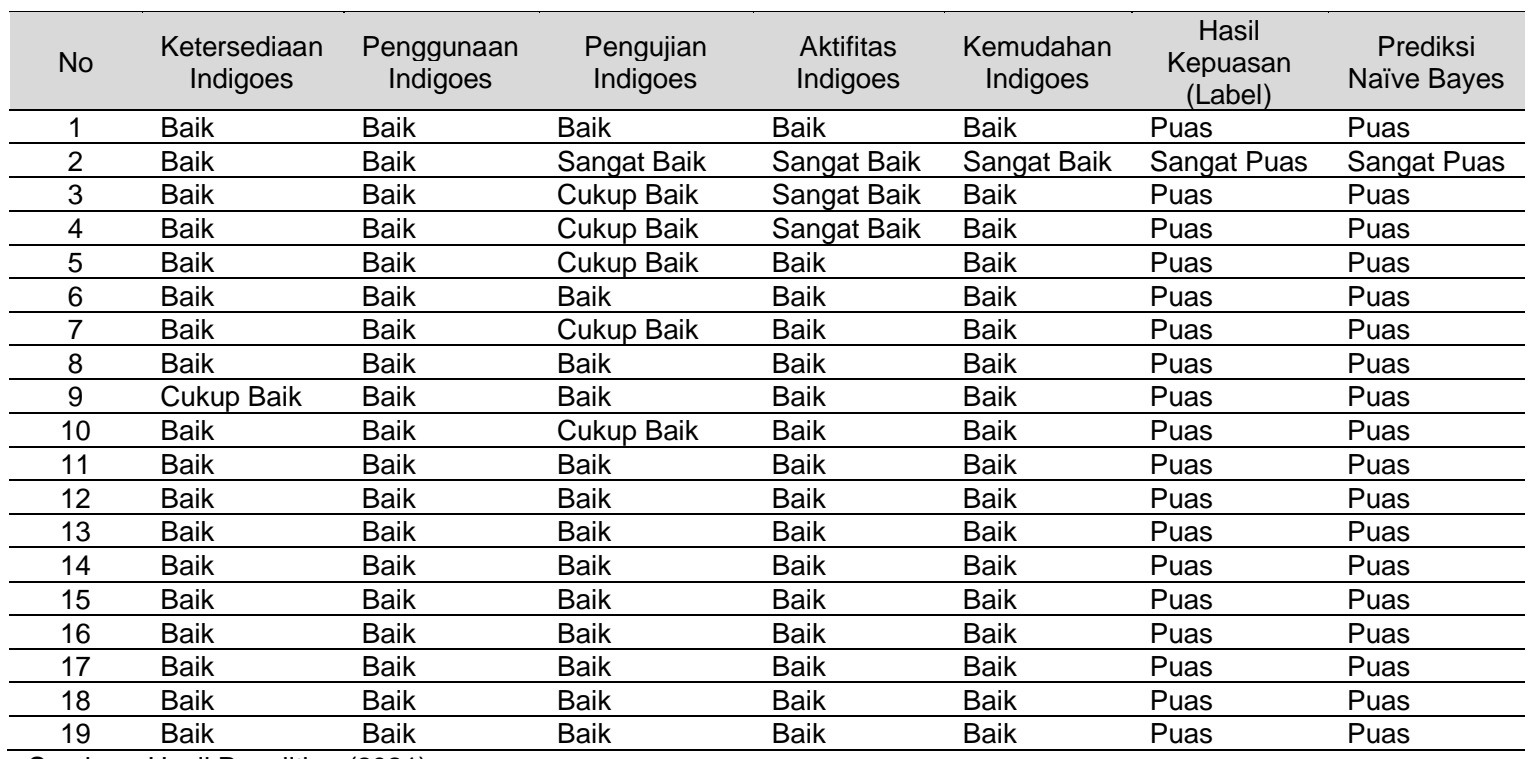

Sumber : Hasil Penelitian (2021)

Hasil tersebut diambil dari data testing untuk diketahui Hasil kepuasan dihitung secara manual menggunakan algoritma Naïve Bayes Classifier. Setelah dilakukan perhitungan menggunakan Naïve Bayes Classifier, maka hasil frekuensi nya kategori Sangat Puas terdapat 
1, kategori Puas terdapat ada 18, kategori Cukup Puas 0, dan kategori Tidak Puas 0.hasil dari 19 data uji yang dihitung secara manual dapat dilihat pada tabel 4 .

Tabel 4 Frekuensi data testing

Sumber : Hasil Penelitian (2021)

\begin{tabular}{lc}
\hline Kategori & Frekuensi \\
\hline Sangat Puas & 1 \\
\hline Puas & 18 \\
\hline Cukup Puas & 0 \\
\hline Tidak Puas & 0 \\
\hline
\end{tabular}

Tabel 5 Confusion Matrix

Sumber : Hasil Penelitian (2021)

\begin{tabular}{lccc}
\hline \multirow{2}{*}{ Kategori } & \multicolumn{3}{c}{ Confusion Matrix } \\
\cline { 2 - 4 } & Sangat Puas & Puas & Cukup Puas \\
\hline Sangat Puas & 1 & 0 & 0 \\
\hline Puas & 0 & 18 & 0 \\
\hline Cukup Puas & 0 & 0 & 0 \\
\hline
\end{tabular}

\section{Pembahasan Pengujian Algoritma Naive Bayes Classifier Pada Rapid Miner}

Berdasarkan hasil penelitian dengan perhitungan secara manual diatas, maka peneliti akan mengklasifikasikan data testing pada aplikasi Rapidminer menggunakan algoritma Naïve Bayes Classifier untuk diuji. Kemudian menggunakan fitur read excel untuk membaca data uji.

Di dalam proses pengujian yang terdapat pada Gambar 2 diatas dengan algoritma naïve bayes classifier, dataset akan dibaca dengan menggunakan Read Excel, kemudian dilakukan Split Data untuk menentukan training dan testing. Kedua data tersebut masing-masing ditempatkan pada Store Data terdiri dari Store Data Training dan Store Data Testing. Pada store data training peneliti menggunakan algoritma Naïve Bayes Classifier. Kemudian dihubungkan dengan Apply Model pada store data testing dan Performance untuk diketahui hasil akurasi.

Pada Gambar 3 diatas merupakan proses import data untuk memasukan dataset yang akan diuji pada proses read excel. Kemudian dihubungkan dengan split data.Pada proses split data kemudian dilakukan edit parameter untuk menentukan training $0.8(80 \%)$ dan testing 0.2 $(20 \%)$. Hasil proses klasifikasi menggunakan metode naïve bayes classifier pada data testing yang berjumlah 19 record dihasilkan klasifikasinya sebagai berikut:

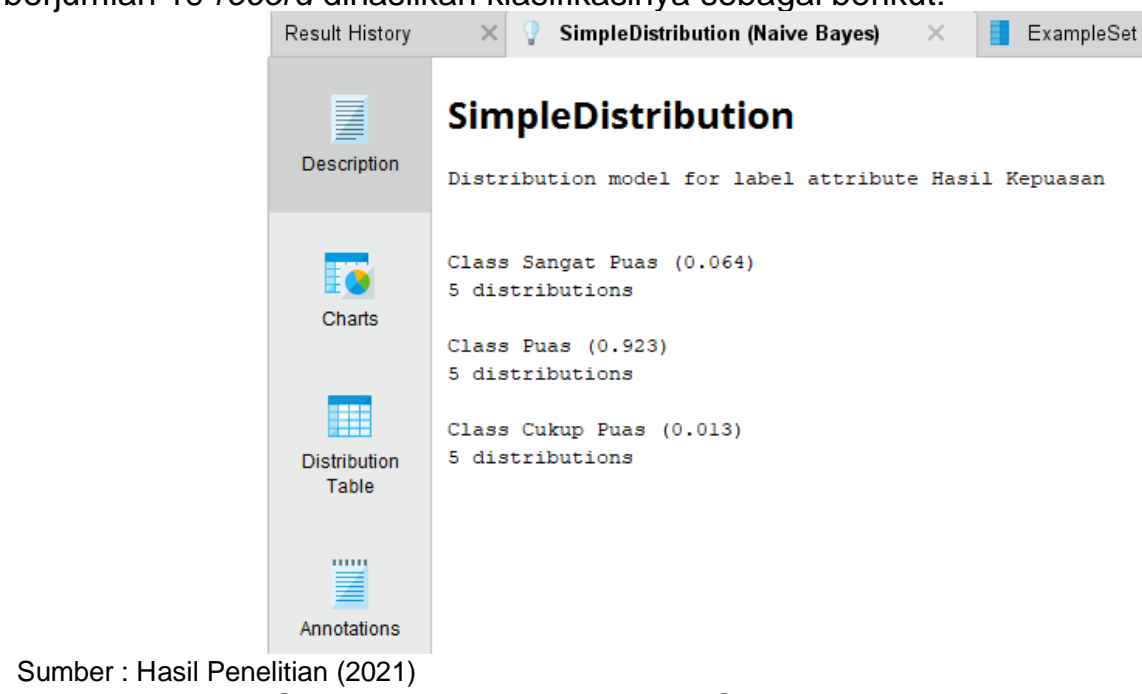

Gambar 1 Probabilitas Hasil Sistem Pembelajaran 
Pada Gambar 1 diatas merupakan nilai probabilitas menggunakan algoritma naïve bayes classifier. Terdapat nilai probabilitas dari label atribut hasil kepuasan mahasiswa yaitu sangat puas nilai probabilitas 0.064 , puas 0.923 dan cukup puas 0.013 . Kemudian dari hasil tersebut menghasilkan tingkat akurasi terhadap penerapan menggunakan algoritma naïve bayes classifier seperti pada gambar dibawah ini:

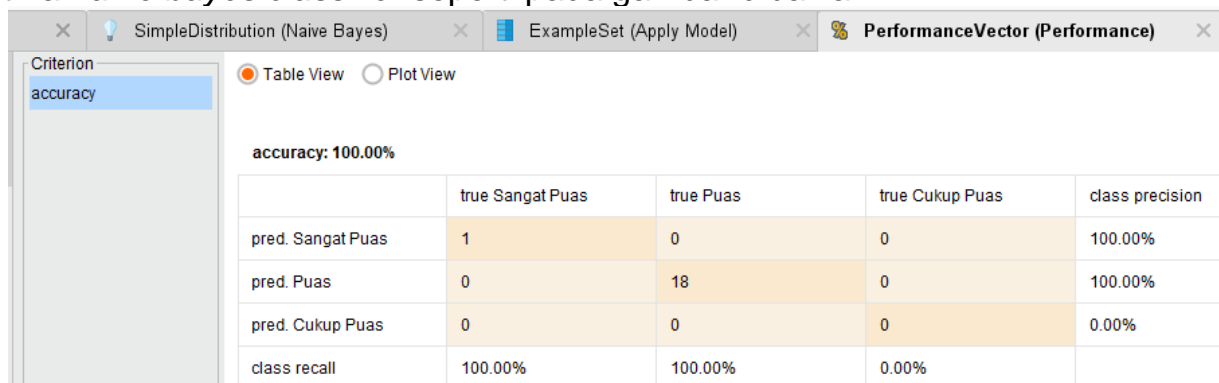

Sumber : Hasil Penelitian (2021)

Gambar 2 Akurasi Hasil Naïve Bayes Classifier

Berdasarkan Gambar 2 diatas diperoleh nilai hasil akurasi 100\% dan terdapat hasil klasifikasi yaitu pada true.Sangat Puas terdapat 1 sebagai pred.Sangat Puas benar dengan class precision $100 \%$ dan class recall $100 \%$, true.Puas terdapat 18 sebagai pred.Puas benar dengan class precision $100 \%$, class recall $100 \%$, dan pada true.Cukup Puas tidak terdapat pred.Cukup Puas. Dari hasil klasifikasi menggunakan naïve bayes classifier maka dihasilkan bentuk confusion matrix sebagai berikut:

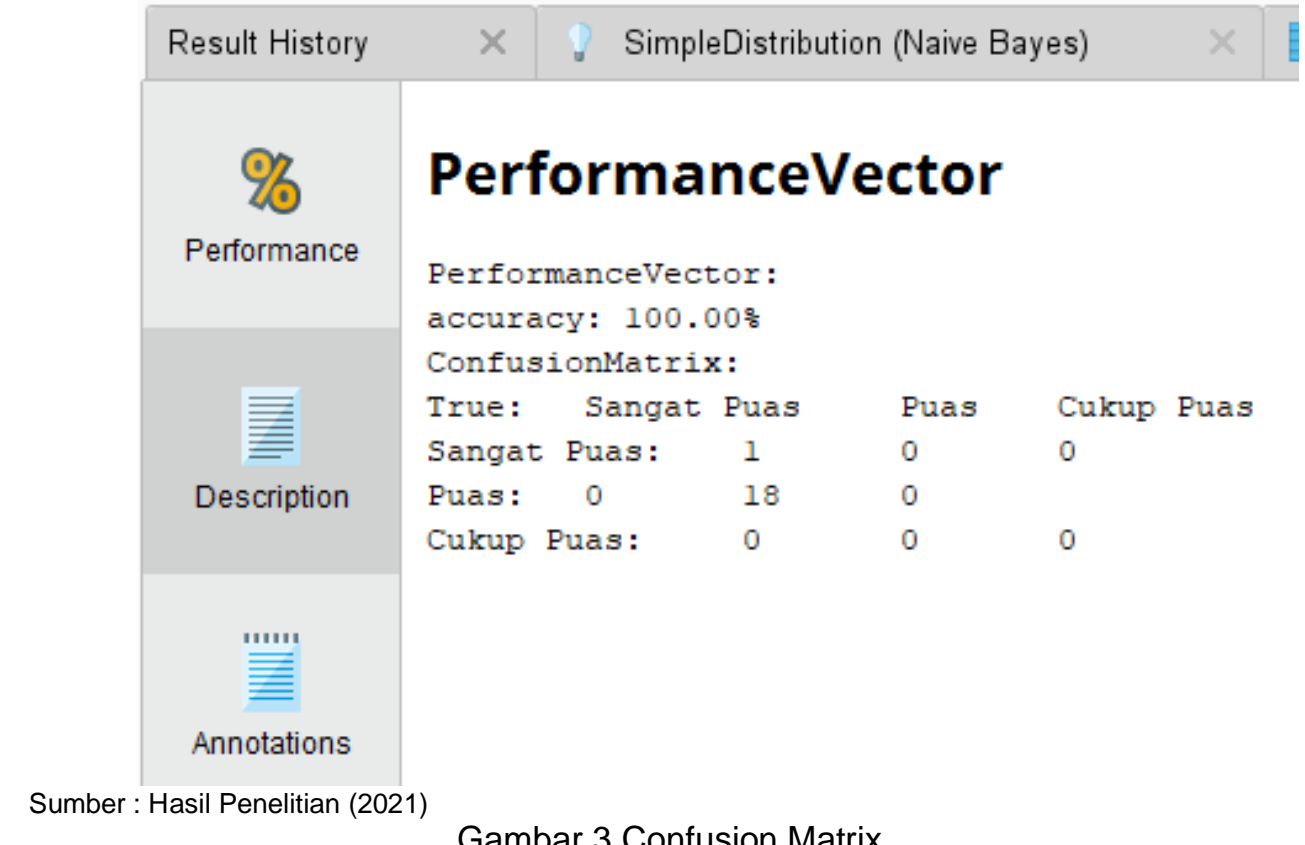

Dengan menggunakan pemodelan naive bayes classifier seperti gambar di atas dengan mengklasifikasi hasil tingkat kepuasan mahasiswa terdapat 2 kategori yaitu Sangat Puas, Puas dan Cukup Puas. Berikut ini adalah hasil implementasi yang ditampilkan berupa Chart pada naïve bayes classifier berdasarkan hasil kepuasan mahasiswa terhadap e-learning dimasa pandemic covid-19, yaitu hasil "PUAS" di STMIK IKMI Cirebon. 
Vol. 5, No. 2, Juni 2021, $137-146$

E-ISSN: 2548-3412

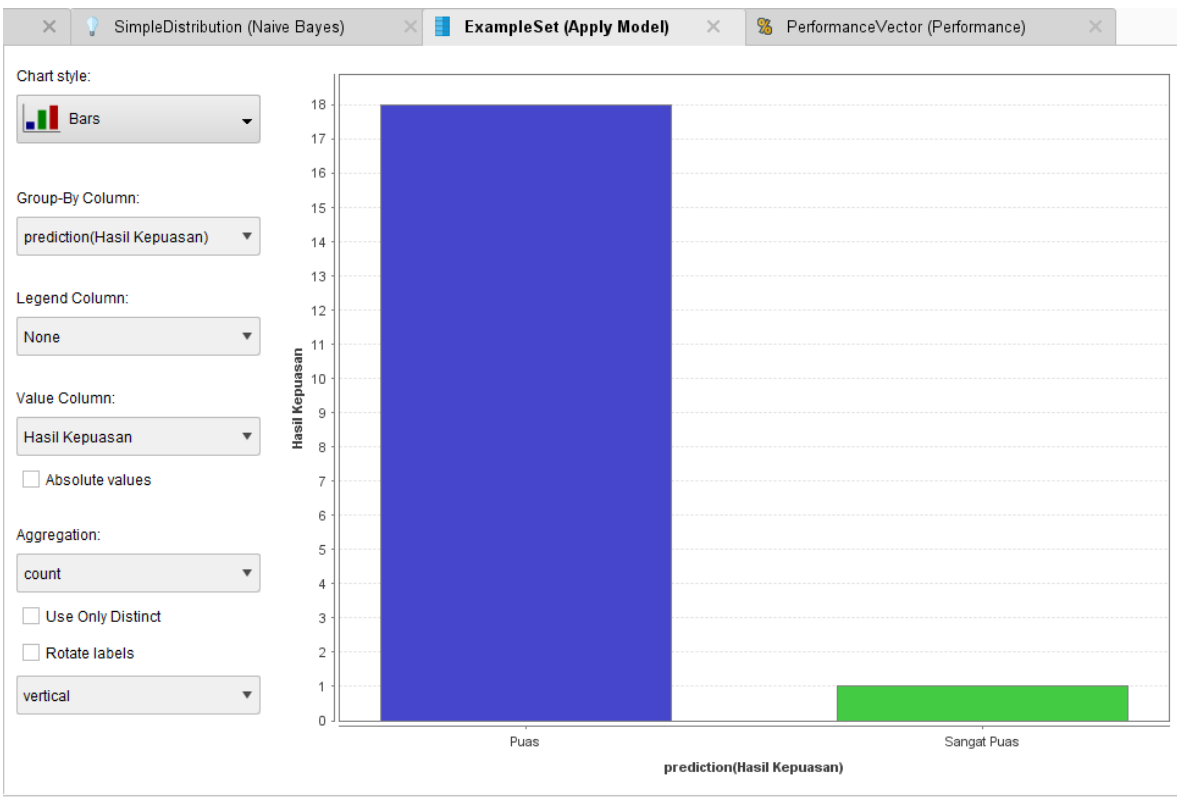

Sumber : Hasil Penelitian (2021)

Gambar 4 Grafik Hasil Kepuasan Mahasiswa

Dari hasil proses yang dijalankan mendapatkan hasil yaitu sebuah probabilitas kemunculan setiap nilai dari masing-masing atribut. Hasil probabilitas yang telah diproses dapat terlihat pada gambar berikut ini:

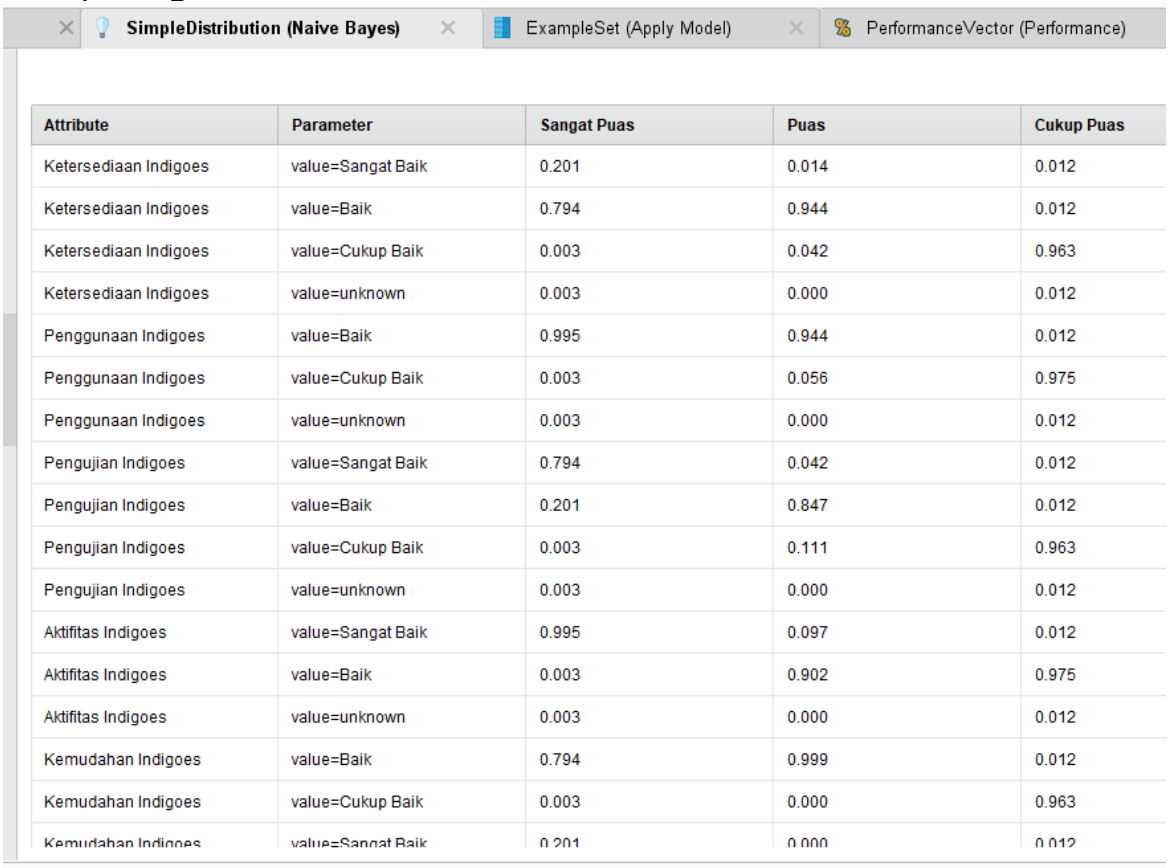

Sumber : Hasil Penelitian (2021)

Gambar 5 Hasil Probabilitas Naïve Bayes

\section{Kesimpulan}

Berdasarkan analisis dan hasil pengujian yang telah dilakukan, maka dapat diambil kesimpulan [1]Dari hasil penelitian yang dilakukan mengklasifikasikan tingkat kepuasan mahasiswa terhadap e-learning pada pembelajaran mahasiswa kelas reguler sore dimasa pandemic covid-19 dapat disimpulkan bahwa hasil klasifikasi kepuasan mahasiswa terhadap e- 
learning melalui dalam jaringan dimasa pandemic covid-19 terhadap kepuasan mahasiswa pada saat pembelajaran melalui dalam daring yaitu "Puas". Hal ini diketahui dari hasil perhitungan menggunakan algoritma naïve bayes classifier. Karena nilai probabilitas class Sangat Puas dan class Cukup Puas lebih kecil dari nilai probabilitas class Puas, maka hasil kepuasan mahasiswa dikatakan sebagai kategori "PUAS".[2]Hasil pengujian pada rapid miner dengan metode klasifikasi naïve bayes classifier terhadap dataset yang telah diambil pada objek penelitian diperoleh tingkat akurasi sebesar $100 \%$ atau termasuk dalam kategori puas, diambil dari data uji sebanyak 19 record.[3]Diketahui dari hasil klasifikasi naïve bayes di Rapid Miner berdasarkan parameter hasil kepuasan mahasiswa terhadap e-learning terdapat kategori puas dan sangat puas. Menunjukan kategori puas lebih lebih tinggi dibanding sangat puas terhadap terhadap pembelajaran melalui e-learning dimasa pandemic covid-19, sehingga hasil yang didapat yaitu hasil "PUAS" pada pembelajaran menggunakan e-learning melalui dalam jaringan dimasa pandemic covid-19 mahasiswa STMIK IKMI Cirebon.

\section{Referensi}

[1]. Dikananda, A. R., Santoso, H. B., Dana, R. D., \& Sudrajat, D. (2019). E-Learning Usability Evaluation Menggunakan Fuzzy Logic dan Usulan Alternatif Desain Interaktif Learning Management System (LMS) Chamilo. Jurnal ICT: Information Communication \& Technology, 18(1), 65-70. https://doi.org/10.36054/iict-ikmi.v18i1.56

[2]. Sukmanasa, E., Novita, L., \& Siti, F. (2017). ANALISIS KEPUASAN MAHASISWA TERHADAP KINERJA DOSEN PROGRAM STUDI PENDIDIKAN GURU SEKOLAH DASAR UNIVERSITAS PAKUAN. Pedagonal: Jurnal IImiah Pendidikan, 1(2), 91-99. https://doi.org/10.33751/pedagog.v1i2.390

[2]. Andreanus, J., \& Kurniawan, A. (2018). Sejarah, Teori Dasar dan Penerapan Reinforcement Learning: Sebuah Tinjauan Pustaka. Jurnal Telematika, 12(2), 113-118.

[3]. Handayani, F., \& Pribadi, S. (2015). Implementasi Algoritma Naive Bayes Classifier dalam Pengklasifikasian Teks Otomatis Pengaduan dan Pelaporan Masyarakat melalui Layanan Call Center 110. 7(1).

[4]. Fitriani, S., Informatika, T., Teknik, F., \& Sidoarjo, U. M. (2019). Penerapan Data Mining Menggunakan Metode Klasifikasi Naïve Bayes untuk Memprediksi Partisipasi Pemilihan Gubernur. 3(2), 98-104.

[5]. Hartatik, Andri Syafrianto, W. W. (2017). PERBANDINGAN KLASIFIKASI PECEMARAN AIR SUNGAI DENGAN METODE BACKPROPAGATION DAN NAÏVE BAYES. Vol. 18. N, 67-71.

[6]. Suherman, A. H. dan. (2019). Prediksi Kehadiran Masyarakat Dalam Pemilihan Umum Dengan Menggunakan Metode Naïve Bayes Classification. 3, 97-99.

[7]. Nofitri, R., \& Irawati, N. (2019). ANALISIS DATA HASIL KEUNTUNGAN MENGGUNAKAN SOFTWARE RAPIDMINER. V(2), 199-204.

[8]. Ryan Dwi Pambudi, Ahmad Afif Supianto, N. Y. S. (2019). Prediksi Kelulusan Mahasiswa Berdasarkan Kinerja Akademik Menggunakan Pendekatan Data Mining Pada Program Studi Sistem Informasi Fakultas Ilmu Komputer Universitas Brawijaya. Jurnal Pengembangan Teknologi Informasi Dan IImu Komputer 2196, 3(3), 2194-2200.

[9]. Prof. Dr. Sugiyono, Statistika Untuk Penelitian. 2012 